\title{
PENGEMBANGAN MODUL BERBASIS STEM (SCIENCE, TECHNOLOGY, ENGINEERING AND MATHEMATICS) PADA POKOK BAHASAN ELEKTROKIMIA
}

\section{DEVELOPMENT MODULE BASED ON STEM (SCIENCE, TECHNOLOGY, ENGINEERING AND MATHEMATICS) IN ELECTROCHEMISTRY}

\author{
Mega Syahirah*, Lenny Anwar dan Betty Holiwarni \\ Program Studi Pendidikan Kimia, Fakultas FKIP Universitas Riau, Pekanbaru, Indonesia \\ *Email: megasyah0731@gmail.com
}

Diterima: 31 Desember 2019. Disetujui: 8 Januari 2020. Dipublikasikan: 3 September 2020

\begin{abstract}
Abstrak: Penelitian pengembangan modul berbasis STEM (Science, Technology, Engineering, and Mathematics) pada pokok bahasanelektrokimia ini bertujuan untuk mengembangkan modul berbasis STEM pada pokok bahasan elektrokimia kelas XII SMA/MA, mengetahui kevalidan modul berbasis STEM pada pokok bahasan elektrokimia berdasarkan aspek kelayakan isi, penyajian, bahasa, STEM serta kegrafisan, dan mengetahui respon pengguna terhadap produk modul berbasis STEM pada pokok bahasan elektrokimia. Prosedur pengembangan penelitian yang dikembangkan adalah model pengembangan ADDIE (Analisis, Perancangan, Pengembangan, Implementasi dan Evaluasi). Namun penelitian hanya dilakukan hingga tahap Pengembangan. Hasil dari pengembangan ini menunjukkan bahwa modul layak digunakan dengan baik dengan penilaian kelayakan modul oleh para ahli sebesar 90,64\%. Untuk respon pengguna modul dapat digunakan dengan baik dengan skor sebesar (88,19\% guru dan $94 \%$ peserta didik).
\end{abstract}

Kata Kunci: Pengembangan, Modul, STEM

Abstract: Research development of chemical module based on STEM (Science, Technology, Engineering and Mathematics) in electrochemistry to of this research is to describe product development in the form of chemical module based on STEM in Electrochemistry, describe the module validation result based on genuie, matter, languange, STEM and Graphic and to know the teacher's and student's response to chemical module based on STEM which has been developed. This type of research is development research using ADDIE (Analysis, Design, Development or Production, Implementation or Delivery and Evaluations) but this stage is only done until development stage. The module developed is validated by 3 validators. Validation test result is $90,64 \%$ with valid category. The response of chemistry teachers as a user has also been categorized either by the value of $88,19 \%$. This assessment was conducted by 2 chemistry teachers at different schools. While Student response to using chemical module based on STEM is done in SMAN 9 Pekanbaru and SMAN 10 Pekanbaru which in general is very good with the percentage of response is $94 \%$. From the results of the average overall score of validation and testing of chemical module based on STEM were valid and can be used as a learning module.

Keyword: Modules, STEM, Electrochemistry

\section{PENDAHULUAN}

Memasuki abad ke-21, sistem pendidikan nasional menghadapi tantangan yang sangat kompleks dalam menyiapkan kualitas sumber daya manusia (SDM) yang mampu bersaing di era global. Upaya yang tepat untuk menyiapkan SDM yang berkualitas dan satu-satunya wadah yang dapat dipandang dan seyogiyanya berfungsi sebagai alat untuk membangun SDM yang bermutu tinggi adalah pendidikan [1].

Masa mendatang, kita akan menghadapi beberapa tantangan dan perubahan yang menuntut perubahan paradigma pendidikan tradisional yang selama ini diterapkan oleh guru di Indonesia. Siswa harus dapat mencari informasi sendiri, mampu mengidentifikasi dan merumuskan masalah, mampu berkerja efektif didalam kelompok, dan membangun jaringan, serta memiliki kreatifitas yang tinggi [2].
Mengikuti standar kurikulum 2013 revisi tahun 2017, kemampuan yang diperlukan pada pendidikan di abad ke-21 yaitu : 1) keterampilan belajar dan berinovasi yang meliputi berpikir kritis dan mampu menyelesaikan masalah, kreatif dan inovatif, serta mampu berkomunikasi dan berkolaborasi; 2) terampil untuk menggunakan media, teknologi, informasi, dan komunikasi; 3) kemampuan untuk menjalani kehidupan dan karir, meliputi kemampuan beradaptasi, luwes, berinisiatif, mampu mengembangkan diri, memiliki kemampuan sosial dan budaya, produktif, dapat dipercaya, memiliki jiwa kepemimpinan, dan tanggung jawab [3]. Namun kenyataannya, keterampilan berfikir peserta didik masih tergolong rendah khususnya pada bidang sains [4].

Pada era modern pendidikan harus mampu berkontribusi pada kehidupan bermasyarakat, 
produktif, kreatif, dan inovatif [5]. Untuk mengembangkan sumberdaya yang mengumpuni dapat dilakukan dengan menlaksanakan pembelajaran yang mengembangkan keterampilan berpikir dan pemecahan masalah [6].

Proses pembelajaran yang mengembangkan kreatifias, berfikir serta pemecahan masalah bergantung pada peserta didik, pengajar, bahan ajar serta pendekatan pembelajaran yang mampu mengintergrasikan berbagai macam ilmu sains, teknologi, teknik dan matematika [7].

Bahan ajar merupakan aspek penting dalam dunia pendidikan karena merupakan sarana untuk mendukung proses pembelajaran. Bahan ajar berbentuk modul dapat membantu guru sekaligus peserta didik dalam proses pembelajaran. Awalnya guru dianggap sebagai satu-satunya pusat informasi dikelas, sementara peserta didik sebagai informasi pasif. Pada era globalisasi para pendidik bukanlah menjadi satu-satunya sumber belajar tetapi lebih diarahkan sebagai fasilitator yang membantu dan mengarahkan dan mendorong peserta didik didalam pembelajaran.

Bahan ajar adalah sumber ajar yang digunakan untuk membantu guru/instruktur dalam melaksanakan kegiatan belajar mengajar. Bahan yang dimaksud bisa dalam bentuk tertulis maupun tidak tertulis yang disusun secara sitematis, memaparkan gambaran utuh dari kompetensi yang akan dikuasai oleh peserta didik dalam kegiatan pembelajaran. Dengan bahan ajar yang memungkinkan peserta didik untuk dapat menguasai suatu kompetensi atau KD secara sitematis mampu menguasai semua kompetensi secara utuh dan terpadu [3].

Pembelajaran adalah bantuan yang diberikan oleh pendidik agar dapat terjadi proses perolehan ilmu pengetahuan, penguasaan kemahiran, dan tabiat serta sikap dan kepercayaan peserta didik.[8].Didalam pembelajaran kimia sangat erat hubungannya didalam kehidupan sehari-hari dan sangat berkaitan erat dengan alam sehingga peserta didik akan jauh lebih mengenal hubungan-hubungan yang terkait didalam pembelajaran dengan alam.Kimia sebagai proses/metode penyelidikan (inquiry methods) meliputi cara berpikir, bernalar, merumuskan masalah, melakukan percobaan, melakukan pengamatan, menganalisis data, dan menyimpulkan untuk memperoleh produk-produk sains [9].

Pembelajaran peserta didik terhadap konsep IPA seara keseluruhan memerlukan perubahan dimana sebelumnya berupa konvensional menjadi pembelajaran inovatif. Oleh karena itu, guru berperan membimbing peserta didik dalam proses belajar. Proses pembelajaran mengembangkan pengetahuan, kemampuan berpikir, dan keterampilan monotorik peserta didik melalui interaksi langsung berupa kegiatan-kegiatan pembelajaran berbaisis aktifitas. Pembelajaran IPA melibatkan pembelajaran kontekstual (CTL). Pembelajaran konsteksual (Contextual Teaching and Learning (CTL)) merupakan konsep belajar yang membantu guru mengkaitakan antara materi yang diajarkannya dengan situasi dunia nyata dan mendorong pengetahuan yang dimilikinya dengan penerapannya didalam kehidupan sehari-hari [10].

Modul berbasis STEM (Science Technology

Enginerring Mathematics) adalah modul pembelajaran yang mengintegrasikan disiplin ilmu terkait. Pembelajaran bidang eksakta Sains, Teknologi, Teknik dan Matematika dapat terjadi melalui STEM yakni pembelajaran antar ilmu pengetahuan untuk mempelajari konsep akademis yang dipadukan dengan dunia nyata sebagai pengaplikasian bidang tersebut. Pada pembelajaran STEM peserta didik dituntut untuk memecahkan masalah, membuat pembaruan, menemukan/ merancang hal baru, memahami diri, melakukan pemikiran logis serta menguasai teknologi [11]. Pembelajaran STEM belum begitu populer, tetapi perintegrasian berbagai disiplin ilmu sudah mulai muncul pada kurikulum 2013 [12].

Pembelajaran STEM terdiri atas empat buah aspek yaitu Sains, Teknologi, Teknik dan matematika. Sains adalah aspek mengenai alam, hukum yang diasiosiasikan pada kimia, fisika, biologi, serta fakta, konsep dan prinsip. Aspek Teknologi adalah keterampilan dalam mengorganisasi suatu teknologi, keterampilan dalam mengoprasikan suatu alat. Aspek Teknik adalah pengetahuan dalam merancang dan mengoperasikan suatu prosedur. Aspek Matematika adalah keterampilan dalam menyalurkan ide berdasarkan hukum data, pola, ruang dan memberikan alasan secara efektif [13].

Menurut Sanders, pembelajaran STEM juga mencakup pembelajaran 4C (Creativity, Critical thinking, Collaboration and Communication) yakni pembelajaran yang diperlukan pada abad 21. Peserta didik akan bekerja sama untuk menciptakan suatu inovasi nyata dan mengkomunikasikan solusi kepada peserta didik lainnya. Pada pembelajaran peserta didik akan menginvestigasi, menganalisa informasi yang mereka dapatkan guna menyelesaikan masalah yang didapatkan. Pembelajaran STEM juga akan membangun karakter profesi yang mempunyai skill, manejemen waktu yang baik, bekerja sama sesama rekan, menggunakan teknologi dan juga menggunakan cara yang efektif dalam menyelesaikan suatu permasalahan yang sedang dibahas.

Bidang STEM dilakukan seolah-olah terintegrasi sebagai suatu objek dengan dilakukan sekurang-kurangnya dua disilplin ilmu. Seperti matematika yang diintegrasikan dengan pembelajaran STEM [14]. Pembelajaran STEM mencakup pembelajaran mengintegrasikan sains, 
teknologi, teknik dan matematika yang diterapkan sesuai dengan jenjang pendidikan serta mengarahkan masyarakat khususnya peserta didik untuk menciptakan suatu prosedur inovasi yang baru serta membangun kualitas sumber daya manusia yang berkualitas. STEM juga membangun pengetahuan bakat dan sikap, mengindentifikasikan pertanyaan dan masalah dalam situasi dikehidupan sehari-hari dengan mengangkat masalah terkait sains, teknologi, teknik dan matematika seperti (lingkungan, sumber daya alam, energi baharu dan lainnya) $[15,16]$.

STEM adalah dengan menekankan dan mengangkat pembelajaran pada aspek teknik sebagai bentuk integrasi dari STEM. Aspek "E" inilah yang menjadikan STEM unik dengan pembelajaran lainnya. Pada aspek tersebut peserta didik dapat mengasah kemampuannya dalam merekayasa dan dapat mudah dipratekkan peserta didik didalam kehidupan nyata.

Elektrokimia merupakan salah satu pokok bahasan pada mata pelajaran kimia di kelas XII SMA/MA sederajat. Pokok bahasan elektrokimia meliputi sel volta dan potensial sel, korosi, sel elektrolisis dan hukum faraday. Elektrokimia termasuk materi dengan analisis tinggi karena menyangkut pemahaman konsep dan perhitungan serta keterkaitakn yang sangat erat dengan penerapannya di kehidupan sehari-hari seperti dengan memanfaatkan bahan-bahan alam disekitar yang cenderung membuat peserta didik kesulitan untuk memahaminya. Pada pembelajaran elektrokimia disekolah juga hanya dilakukan sebatas teori tanpa adanya pratikum yang menunjang peserta didik utnuk berpikir secara kreatif dan inovatif. Penggunaan modul dalam pembelajaran elektrokimia dapat menjelaskan materi pokok secara terperinci dan membuat peserta didik dapat belajar secara mandiri. Pada pengitengrasian STEM peserta didik tidak hanya dituntun untuk memahami materi saja tetapi juga dibimbing untuk memberikan solusi untuk menyelesaikan suatu masalah inovasi guna mengembangkan suatu rekayasa dalam merancang suatu desain produk elektrokimia seperti suatu produk sel baterai, pencegahan korosi dan pelapisan logam dalam suatu produk maupun rancangan gambar.

Kelemahan dari pembelajaran STEM ini adalah pembelajaran dapat saja terpotong bila salah satu peserta didik tidak mampu mengkaitkan suatu integrasi ilmu dengan yang lainnya. Peserta didik tersebut hanya akan mendapatkan sebagian manfaat dari pembelajaran STEM [14].

Penelitian terkait pengembangan modul berbasis STEM sebelumnya dilakukan oleh Taza Nur Azmi menghasilkan modul pada pokok bahasan Segi Empat menghasilkan hasil validasi modul kriteria validitas tinggi dengan presentase kriteria validasi isi, media dan bahasa, berturut turut $(87 \%$,
$89 \%, 92 \%)$. Respon Pengguna guru serta peserta didik sebesar $(82.91 \%$ dan $85.91 \%)$ [17].

Berdasarkan uraian diatas, maka penulis melakukan penelitian "Pengembangan Modul Berbasis STEM (Science, Technology, Engineering, and Mathematics) pada Pokok Bahasan Elektrokimia Kelas XII SMA/MA”.

\section{METODE PENELITIAN}

Metode penelitian yang digunakan dalam pengembangan ini adalah model pengembangan ADDIE yang terdiri atas 5 langkah, namun pada pengembangan ini hanya dilakukan 3 langkah yaitu Analisis (Analisis), Perancangan (Design) dan Pengembangan (Development) [18]. Objek penelitian yang dilakukan adalah modul bahan ajar berupa modul berbasis STEM pada pokok bahasan elektrokimia.

Penelitian ini melibatkan para ahli sebanyak tiga orang untuk menilai kelayakan modul berdasarkan aspek isi, penyajian, bahasa, STEM serta grafis dan uji respon pengguna sebanyak 15 orang peserta didik masing-masing di SMA N 9 PEKANBARU dan SMA N 10 PEKANBARU serta 2 orang guru bidang studi kimia.

Instrumen penelitian menggunakan lembar validasi ahli, angket respon pengguna yaitu guru dan peserta didik. Teknik analisis data yang dilakukan adalah teknik analisis deskriptif yaitu menhitung rata-rata tiap aspek pada validasi modul dengan mengubah data kuantitatif menjadi data kualitatif. Data yang diperoleh pada validasi modul oleh para ahli adalah skor dari skala likert $5(5,4,3,2,1)$ dengan keterangan sangat baik, baik, cukup, kurang baik, sangat kurang. Rumus yang digunakan untuk menghitung skor rata-rata dapat dilihat pada persamaan 1

$$
\mathrm{P}=\mathrm{n} / \mathrm{N} \times 100 \%
$$

Keterangan

P: Presentase Skor (\%)

n: skor total yang diperoleh

$\mathrm{N}$ : skor maksimal

Kemudian mengubah data kuantitantif yang didapatkan menjadi kualitatif berasarkan tabek kriteria validitas pada Tabel 1. [19].

Tabel 1 Kriteria Validitas

\begin{tabular}{ll}
\hline Persentase Skor $(\%)$ & Kriteria Validitas \\
\hline $80.00-100$ & Sangat Tinggi \\
$60.00-79.99$ & Tinggi \\
$40.00-59.99$ & Cukup \\
$20.00-39.99$ & Rendah \\
$0.00-19.99$ & Sangat Rendah \\
\hline
\end{tabular}

Setelah dilakukan validasi terhadap modul pembelajaran dengan pendekatan STEM, 
selanjutnya modul diujicobakan kepada peserta didik dan guru untuk mengetahui respon peserta didik terhadap modul pembelajaran yang digunakan. Untuk menganalisis respon guru dan peserta didik menggunakan rumus pada persamaan 1 .

Dalam hal ini pengukuran kepraktisan menggunakan kuesioner respon praktisi (guru dan peserta didik). Kuesioner guru menggunakan Skala Likert berbentuk pilihan ganda dengan empat rentang penilaian, yaitu: 4, 3, 2, dan 1 dengan kriteria sangat setuju (SS), setuju (S), tidak setuju (TS), dan sangat tidak setuju (STS). Sedangkan kuesioner peserta didik menggunakan Skala Guttman dengan dua rentang penilaian, yaitu: skor 1 untuk jawaban 'Ya' dan 0 untuk jawaban 'Tidak'. Kemudian untuk respon pengguna oleh guru digunakan krietia kepraktisan pada Tabel 2 [20]

Tabel. 2 Kriteria Validitas

\begin{tabular}{ll}
\hline Persentase Skor $(\%)$ & Kriteria Validitas \\
\hline $75.00-100$ & $\begin{array}{l}\text { Dapat digunakan } \\
\text { tanpa revisi }\end{array}$ \\
Dapat digunakan \\
sedikit reivsi \\
se-00-74.99 & $\begin{array}{l}\text { Dapat digunakan } \\
\text { banyak revisi } \\
\text { Tidak dapat } \\
\text { digunakan }\end{array}$ \\
\hline
\end{tabular}

\section{HASIL DAN PEMBAHASAN}

Produk yang dihasilkan dari penelitian pengembangan berupa modul kimia berbasis STEM pada pokok bahasan elektrokimia. Modul ini diharapkan menjadi bahan ajar bagi guru sebagai pendidik dalam proses pembelajaran dikelas dan sebagai sumber belajar mandiri oleh peserta didik.

\section{Analisis}

Analisis kebutuhan dillakukukan guna mengetahui permasalahan mendasar sehingga diperlukan pengembangan sumber belajar melalui hasil wawancara dengan beberapa guru kimia SMA di Pekanbaru. Pada tahap ini diperoleh data bahwa bahan ajar yang digunakan selama ini masih menggunakan bahan ajar masih terbatasnya bahan ajar yang memfasilitasi perserta didik dalam membangun konsep dan pengetahuan secara mandiri dan mengkaitkan materi dengan kehidupan seharhari serta belum mengarah pada pembelajaran yang inovatif

Selanjutnya pada tahap analisis dilakukan analisis struktur materi, indikator pencapaian kompetensi dan konsep berdasarkan silabus 2017. Analisis ini dirancang bersama pembimbing agar menghasilkan modul yang sesuai dengan kurikulum 2013 dan membantu peserta didik dalam memahami materi pembelajaran. Diskusi yang dilakukan bersama pembimbing antara lain menentukan isi modul dengan menganalisis silabus sesuai kurikulum berdasarkan materi yang dikembangkan yaitu elekrokimia. Analisis materi elektrokimia berdasarkan kompetensi dasar yang merujuk pada silabus sehingga menghasilkan indikator pencapaian kompetensi (IPK) dan tujuan pembelajaran yang akan dituang kedalam modul. Tujuan pembelajaran perlu dirumuskan karena akan dijadikan acuan dalam proses pembelajaran dan juga memfokuskan materi yang akan diajarkan dari IPK dan tujuan pembelajaran didapatkan konsep-konsep utama yang akan diajarkan didalam modul, selanjutnya digambarkan menjadi pera konsep yang berisikan tentang pokok-pokok bahasan elektrokimia yang akan dipelajari dalam modul. Konsep utama yang dihasilkan dapat dikembangkan dan disajikan dalam modul. Materi elektrokimia menggabungkan antara konsep, perhitungan, dan pratikum yang dikembangkan secara menarik agar peserta didik dapat termotivasi mempelajari suatu materi.

Nilai-nilai STEM yang diintegrasikan dalam modul juga didiskusikn bersama pembimbing. Hasil diskusi berupa pemilihan nilai- nilai STEM pada materi yang dipaparkan didalam modul sesuai dengan sesuai dengan kurikulum 2013.

\section{Perancangan}

Pada tahap perancangan dilakukan dengan penyusunan awal modul yang mencakup penetapan judul, materi modul, latihan dan nilai-nilai STEM dalam modul. Penyusunan modul dilakukan dengan menyusun hasil analisis kurikulum, konsep materi, serta penyusunan judul kegiatan belajar. Berdasarkan analisis Kompetansi Dasar (KD) pada pokok bahasan elektrokimia, dapat diketahui banyaknya kegiatan belajar dan judul setiap kegiatan belajar. Modul ini disusun terdiri dari 3 kegiatan belajar yaitu: Kegiatan Belajar I, Kegiatan Belajar II, dan Kegiatan Belajar III dengan judul berturut-turut adalah Sel Volta, Korosi dan Sel Elektrolisis.

Penyusunan materi disusun berdasarkan KD yang akan dicapai oleh peserta didik menggunakan refrensi-refrensi kimia tingkat perguruan tinggi dan buku teks kimia SMA didukung oleh ilustrasi yang mampu menunjang isi materi. Penyusunan modul dirancang dengan tampilan tampilan menarik, penuh warna disertai dengan ilustrasi dan halaman sampul yang berbeda disetiap kegiatan belajar. Hal ini bertujuan sebagai daya tarik peserta didik terhadap modul sehingga modul lebih mudah dipahami dan menarik untuk dipelajari.

Rancangan awal modul berbasis STEM dengan pendekatan tertanam [21] adalah merumuskan indicator pencapaian kompetensi pada elektrokimia berdasarkan silabus kimia edisi 2017. Modul berbasis STEM memiliki kegiatan agar peserta didik mampu mengidentifikasi masalah, 
memberikan suatu ide inovatif serta merancang suatu produk.

Modul dirancang menjadi tiga kegiatan belajar yaitu sel volta, korosi, sel elektrolisis. Format langkah yang terdapat pada modul yaitu (1) Obeserve (2) New Idea (3) Innovation (4) Creatifity (5) Society [22].

Pembuatan lembar validasi juga dilakukan pada tahap perancangan. Desain lembar validasi disusun merujuk kepada Badan Standar Nasional Pendidikan (BSNP 2014) mengenai instrument penilaian bahan ajar Lembar validasi terdiri dari dua jenis yaitu validasi ahli materi dan validasi ahli media. Lembar validasi ahli materi terdiri dari 4 aspek yakni isi, sajian, bahasa dan STEM dengan total pertanyaan 40 soal sedangkan lembar validasi media terdiri dari aspek kegrafisan dengan pertanyaan 20 soal.

Pembuatan lembar tanggapan guru dan peserta didik juga dirancang pada tahap ini yang bertujuan untuk menilai aspek keefektifan modul berbasis STEM. Desain lembar tanggapan pengguna oleh guru dan peserta didik diperoleh dan dirancang sesuai dengan kebutuhan penelitian dengan merujuk pada lembar tanggapan pada penelitian sebelumnya yang relevan.

\section{Pengembangan}

Rancangan awal modul didiskusikan bersama dosen pembimbing agar mendapat saran-saran untuk pengembangan modul sebelum dilakukan validasi. Modul dikembangkan mengacu pada Panduan Pengembangan Bahan Ajar yang meliputi cover, daftar isi, glosarium, kompetensi dasar, petunjuk penggunaan, peta konsep, materi, tujuan pembelajaran, rangkuman, tugas, penilaian diri, tes sumatif, kunci jawaban, dan daftar pustaka.[9]

Tahap pengembangan dilakukan dengan validasi dan revisi sehingga mendapatkan modul berbasis STEM pada pokok bahasan elektrokimia yang valid. Tujuan dilakukan validasi modul adalah untuk mengetahui kelayakan penggunaan modul dalam kegiatan pembelajaran.

Produk modul yang telah dirancanng selanjutnya divalidasi oleh para ahli dengan penilaian validasi oleh ahli untuk mengetahui kualitas rata-rata dari produk. Perolehan skor ratarata dari validasi dapat dilihat pada tabel 3

Tabel 3. Perolehan skor rata- rata dari validasi

\begin{tabular}{ll}
\hline Aspek Skor & Skor Rata-rata \\
\hline Kelayakan Isi & $88 \%$ \\
Penyajian & $90.63 \%$ \\
Bahasa & $88.83 \%$ \\
STEM & $90 \%$ \\
Grafis & $92 \%$ \\
\hline
\end{tabular}

Validasi Aspek Kelayakan Isi terdiri atas 10 komponen penilaian yang bertujuan untuk menilai ketepatan konsep kimia pada pokok bahasan elektrokimia. Validasi Aspek Penyajian memiliki 12 komponen yang bertujuan untuk menilai kualitas penyajian modul berbasis STEM pada pokok bahasan elektrokimia. Validasi Aspek Bahasa memiliki 12 komponen penilaian yang bertujuan untuk menilai tingkat keterbacaan dan penggunaan bahasa didalam modul. Validasi Aspek STEM memiliki 6 komponen penilaian yang bertujuan untuk menilai nilai-nilai STEM yang terkandung didalam modul. Validasi Aspek Kegrafisan memiliki 20 komponen penilaian yang bertujuan untuk menilai modul secara fisik, ketetapan tata letak (layout), tulisan, gambar/ilustrasi dan desain modul.

Pada aspek kelayakan isi menurut validator modul yang dikembangkan sesuai dengan KD 3.4, 3.5 dan 3.6 dan materi yang disajikan dalam modul sudah sesuai dengan substansi materi alam elektrokimia. Pada komponen 4 dan 5 yaitu keakuratan konsep dan keakuratan fakta masingmasing mendapatkan $50 \%$ pada validasi I karena validator menilai masih kurangnya penegasan terhadap materi maupun fakta didalam modul yang akan menimbulkan banyak tafsir sehingga diperlukan sebuah kalimat penegasan didalam modul agar tidak menimbulkan banyak tafsir. Setelah dilakukan revisi masing-masing mendapatkan kelayakan sebesar $90 \%$ pada validasi II. Pada komponen 2 dan 3 mendapatkan skor sebesar $80 \%$ karena validator menilai materi yang disajikan mencerminkan jabaran pendukung capaian elektrokimia dan juga tampilan, kasus, dan contoh dengan baik. Pada komponen 9 dan 10 yaitu mendorong rasa ingin tahu dan mendorong keingin tahuan lebih tinggi mendapatkan skor 90\%. Tim Validator menilai uraian latihan, kasus serta link web simulasi yang diberikan dapat mendorong rasa keingintahuan peserta didik lebih jauh. Skor total validasi I pada aspek kelayakan isi adalah $76 \%$ dengan kategori kevalidan tinggi. Namun untuk memaksimalkan produk yang dikembangkan diperlukan perbaikan sehingga dihasilkan persentase $88,83 \%$ kemudian validasi II dengan kategori kevalidan sangat tinggi dan layak digunakan.

Validasi Aspek Penyajian terdiri atas 12 komponen guna untuk menilai kualitas penyajian modul berbasis STEM pada pokok bahasan elektrokimia. Pada komponen 1,2,3,4, dan 5 yaitu konsistensi penyajian, kesesuaian materi dengan ilustrasi, advance organizer, contoh soal, peta konsep dan rangkuman mendapatkan skor masingmasing $80 \%$. Tim validator menilai masih terdapat ilustrasi yang kurang sesuai, peta konsep yang kurang sesuai, kemudian wacana yang digunakan kurang untuk memotivasi perserta didik, terdapat penjelasan contoh soal yang kurang sesuai. Setelah 
dilakukan revisi didapatkan skor pada validasi II sebesar $90 \%$ untuk komponen 1,3,4,5 sedangkan komponen 2 didapatkan skor $100 \%$. Pada komponen $6,7,9$, dan 10 yaitu soal latihan pada akhir kegiatan, kunci jawaban, pendekatan ilmiah serta pendahuluan didapatkan skor masing-masing $70 \%$ pada validasi I.Tim validator menilai terdapat soal objektif yang dinilai kurang sesuai dengan materi, kunci jawaban yang salah serta perlu dituliskan kunci jawaban secara lengkap tidak hanya option (A,B,C,D,E), terdapat deskripsi modul yang tidak menggambarkan basis STEM, pertunjuk penggunaan modul yang masih kurang jelas. Setelah dilakukan revisi didapatkan skor masing-masing komponen sebesar $90 \%$. Tim validator menilai komponen sudah mempunyai pendahulan yang jelas sehingga pengguna dapat mengerti basis modul yang dikembangkan, petunjuk penggunan modul, dan soal-soal yang benar serta kunci jawaban yang jelas. Pada komponen 11 dan 12 yaitu glossarium dan daftar pustaka tim validator menilai penyusunan daftar istilah penting beserta penjelasannya kemudian daftar buku yang menjadi daftar rujukan dengan baik. Skor total validasi I pada aspek penyajian adalah $76,67 \%$ dengan kategori kevalidan tinggi kemudian pada validasi II dihasilkan persentasi kelayakan sebesar 90,83\% dengan kategoti kevalidan sangat tinggi dan layak digunakan.

Validasi Aspek Bahasa terdiri atas 12 komponen penilaian yang bertujuan untuk menilai tingkat keterbacaan dan penggunaan bahasa didalam modul. Pada komponen 2,3,4, dan 5 yaitu kesesuaian materi dengan materi, memotivasi peserta didik, kesesuaian dengan perkembangan peserta didik, ketepatan struktur kalimat mendapatkan skor masing-masing $70 \%$ pada validasi I. Tim validator menilai penjelasan ilustrasi sudah sesuai dengan apa yang dipaparkan, kalimat yang dijelaskan mewakili pesan atau informasi yang ingin disampaikan pada nateri elektrokimia, serta sesuai dengan tingkat perkembangan kognitif dan emosional peserta didik. Tetapi terdapat struktur kalimat yang kurang sesuai dengan tata kalimat Bahasa Indonesia sehingga perlu dilakukan sedikit revisi. Setelah dilakukan revisi didapatkan skor ssebesar $90 \%$ pada setiap masing-masing komponen. Pada komponen lainnya didapatkan skor $60 \%$ pada validasi I hal ini dikarenakan masih banyak terdapat penggunaan istilah yang tidak konsisten contoh: katoda dan catode maupun anoda dan anode, kemudian terdapat beberapa kalimat typo, dan juga nama penggunaan simbol yang kurang rapi. Setelah dilakukan revisi pada Validasi II didapatkan skor $80 \%$ pada komponen 6 dan 9 kemudian $90 \%$ pada komponen 1,7,8,10, dan 12 serta $100 \%$ pada komponen 11 . Tim validator menilai bahwa penggunanan istilah sudah konsisten, perbaikan typo sudah lebih baik. Skor total Validasi
I pada aspek bahasa adalah 63,33\% termasuk dalam kategori ke-validan tinggi namun masih perlu dilakukan revisi untuk didapatkan penilaian yang lebih maksimal sehingga pada Validasi II didapatkan skor sebessar $88,33 \%$ dan masuk kategori sangat tinggi.

Validasi Aspek STEM terdiri atas 6 komponen penilaian yang bertujuan untuk menilai nilai-nilai STEM yang terkandung didalam modul. Pada komponen 1 dan 2 yaitu kemampuan peserta didik bekerja sama untuk membuat suatu inovasi dan membuat hubungan pengetahuan yang dimilikinya dengan penerapannya dengan kehidupan sehari-hari mendapatkan skor $80 \%$. Tim validator menilai bahwa modul dapat membantu peserta didik untuk menciptakan suatu inovasi dari kasus yang diberikan dan membuat suatu manfaaat dari inovasi yang diciptakan bersama temannya terhadap kehidupan masyarakat. Tidak terdapat perubahan terhadap validasi I dan II pada komponen ini. Kemudian validasi I pada komponen 3 yaitu sains mendapatkan skor $80 \%$. Tim Validator menilai bahwa konsep dan materi pengetahuan sudah sangat baik bisa di perdalam lebih baik lagi kemudian pada validasi II didapatkan skor 90\%. Pada komponen 4 dan 5 yaitu teknologi dan teknik didapatkan skor $90 \%$. Tim validator menilai bahwa aspek menciptakan teknologi maupun poin inovasi dapat membantu anak tersebut merancang inovasi melalui rancangan gambar maupun produk secara langsung. Pada komponen 6 yaitu matematika didapatkan skor $80 \%$. Tim validasi menilai matematika yang terkandung didalam sains sudah baik, peserta didik dapat menghitung nilai matematika yang terkandung didalam materi tersebut, kemudian dapat mengkomuniasikan ide secara efektif. Skor total validasi I pada aspek STEM adalah 83,33\% dengan kategori kevalidan tinggi kemudian pada validasi II dihasilkan persentasi kelayakan sebesar $90 \%$ dengan kategoti kevalidan sangat tinggi dan layak digunakan

Validasi Aspek Kegrafisan terdiri atas 20 komponen penilaian yang bertujuan untuk menilai modul secara fisik, ketetapan tata letak (layout), tulisan, gambar/ilustrasi dan desain modul. Skor rata-rata penilaian validator pada validasi I adalah $79 \%$ termasuk dalam kategori tinggi. Validator menilai bahwa ilustrasi/gambar yang disajikan didalam modul jelas dan berhubungan dengan konsep. Modul memuat jenis huruf yang baik dan dapar dipahami oleh peserta didik. Modul juga memiliki desain tampilan yang menarik dan dekoratif sehingga memotivasi peserta didik untuk memahami isi modul. Tetapi validator menilai pemilihan warna kotak pada setiap fitur-fitur modul belum konsisten pada setiap kegiatan belajar terdapat warna-warna kotak dan ilustrasi yang tidak konsisten, instruksi untuk beberapa kegiatan pembelajaran belum jelas sehingga dapat, sumber- 
sumber ilustrasi yang ditampilkan tidak disajikan sehingga perlu dilakukan revisi pada poin-poin tersebut. Perbandingan beberapa huruf sub judul dan isi naskah tidak konsisten namun tidak fatal. Terdapat beberapa penempatan ruang spasi kosong setiap halaman tidak konsisten, hal ini dikarenakan kebutuhan dari sub materi tersebut dan ada beberapa materi yang ditambah dan juga tidak karena itu penempatan ruang kosong tidak konsisten. Skor rata-rata pada validasi II modul berbasis STEM pada pokok bahasan elektrokimmia adalah $92 \%$. Validator menilai bahwa kesesuaian kalimat, jenis huruf, kemudian warna serta bingkai tiap-tiap fitur didalam modul sudah sangat serasi dan tidak mengganggu pengguna untuk membaca modul. Berdasarkan kriteria kelayakan modul pada Tabel 3.1 maka modul yang dikembangkan pada aspek kegrafisan termasuk dalam kategori sangat tinggi.

Uji coba dilaksanakan kepada dua orang guru dan 30 peserta didik kelas XII MIPA SMA Negeri 9 dan 10 Pekanbaru. Guru dan peserta didik dipilih sebagai responden karena dianggap sebagai pengguna modul pada proses pembelajaran kimia di sekolah. Peserta didik diberikan modul dan diminta untuk mempelajari modul secara keseluruhan dan mengisi lembar angket yang telah diberikan. Masing-masing guru juga diberikan modul, agar dapat menilai modul secara keseluruhan dengan menggunakan lembar respon guru.

Guru menilai bahwa modul berbasis STEM sudah bagus dan dapat digunakan sebagai bahan ajar oleh pendidik didalam proses pembelajaran. Modul juga dilengkapi dengan petunjuk penggunaan sehingga modul bisa digunakan sebagai bahan ajar mandiri oleh peserta didik. Skor rata-rata guru tehadap kepraktisan modul 88,19\%.

Uji coba terbatas selanjutnya dilakukan terhadap 15 orang peserta didik SMAN 9 PEKANBARU dan 15 orang peserta didik SMAN 10 PEKANBARU. Uji coba dilakukan dengan melakukan sosialisasi mengenai modul berbasis STEM kepada peserta didik. Setiap perserta didik diberikan modul untuk dibaca. Peneliti melakukan penjelasan singkat (quick review) kepada peserta didik mengenai materi elektrokimia. Setelah membaca modul secara keseluruhan, peserta didik diberikan kuisioner respon untuk melakukan penilaian terhadap modul.

Persentase rata-rata tanggapan peserta didik adalah 94,44 \%. Berdasarkan kriteria presentase tanggapan maka modul dikategorikan sangat baik. Menurut beberapa tanggapan dari peserta didik bahwa modul STEM dapat menambah wawasan serta memotivasi peserta didik untuk belajar mandiri karena tampilan modul yang menarik. Selain itu tahapan STEM yang digunakan didalam modul memudahkan peserta didik dalam memahami materi yang dipelajari didalam modul.
Pada saat melakukan respon pengguna peserta didik mengaku mengalami kesulitan diawal mengenai pengembangan literasi dan kemampuan sains yang dilakuan hal ini sesuai juga dengan penilitian yang dilakukan oleh Nailul Khairiyah pada tahun 2018 dimana peserta didik yang melakukan uji coba pembelajaran STEM mengalami kesulitan pada pengembangan literasi pengetahuan sains[23] juga Nidaul yang menjabarkan bahwa apabila salah seorang peserta didik kesultan menghubungkan antar ilmu maka akan kurang mendapatkan manfaat dari nilai STEM.[14]

Selain itu respon positif terhadap modul pembelajaran yang diberikan oleh pengguna juga sesuai dengan penelitian oleh Irma pada tahun 2015 pada penelitiannya mengenai Ballon Powered Car sebagai media pemebelajaran berbasis STEM, pada penelitiannya pembelajaran STEM mampu meningkatkan motivasi dan kreasi dalam belajar IPA dan mampu meningkatkan pemahaman peserta didik terutama dalam konsentrasi gerak lurus.[11]

Penelitian yang dilakukan oleh Syukri pada tahun 2013 mengenai pengembangan modul Escit yaitu modul pembelajaran kewirausahaan menggunakan model STEM yang menunjukkan bahwa guru dan peserta didik pada sekolah dasar dan menegah secara keseluruhan memberikan respon yang positif serta mampu meningkatkan minat pesera didik terhadap sains dan juga kemahiran dalam berwirausaha.[22]

\section{KESIMPULAN}

Modul Elektrokimia berbasis STEM yang dikembangkan valid berdasarkan penilaian beberapa aspek yaitu aspek kelayakan isi sebesar $88 \%$, penyajian sebesar $90,83 \%$,bahasa sebesar $88,83 \%$, STEM sebesar $90 \%$ serta aspek grafis sebesar $92 \%$. Secara keseluruhan kevalidan modul elektrokimia berbasis STEM yang dikembangkan adalah 90,64\%. Modul juga dikatakan dapat digunakan tanpa revisi dan dapat diterima dengan baik oleh peserta didik berdasarkan lembar angket respon yang dibagikan. Modul 'dapat digunakan tanpa revisi' berdasarkan respon guru dengan skor rata-rata adalah 88,19\%. Dan Modul 'dapat digunakan dengan baik' berdasarkan uji coba terbatas pada peserta didik dengan skor rata-rata $94 \%$.

\section{DAFTAR RUJUKAN}

[1] Trianto. (2014). Mendesain Model Pembelajaran Inovatif-Progresif: Konsep Landasan dan Implementasi pada Kurikulum 2013. Jakarta: Prenada Media Group.

[2] Ridwan Abdullah Sani. (2015). Pembelajaran Saintifik untuk Implementasi Kurikulum 2013. Jakarta : Bumi Aksara.

[3] Kementrian Pendidikan dan Kebudayaan. (2017). Model Silabus Mata Pelajaran Sekolah 
Menegah atas/Madrasah Aliyah (SMA/MA). Jakarta

[4] Jufri, A. W., \& Hikmawati, H. (2014). Analisis Kemelekan Sains (Science Literacy) Dan Kemelekan Inkuiri (Inquiry Literacy) Guru Mata Pelajaran IPA SMP. Jurnal Pijar Mipa, 9(1).

[5] Rachmawati, D., Suhery, T., \& Anom, K. (2017). Pengembangan modul kimia dasar berbasis STEM problem based learning pada materi laju reaksi untuk mahasiswa program studi pendidikan kimia. In Seminar Nasional Pendidikan IPA (Vol. 1, No. 1, pp. 239-248).

[6] OECD. (2014). PISA in Focus : What 15 years old know and do with what they know

[7] Pertiwi, R.S., Abbdurahman,. Rosidin, Undang. (2017). Efektifitas LKS STEM Untuk Melatih Keterampilan Berfikir Kreatif Siswa. Jurnal Fkip Universitas Lampung.

[8] Muhammad Fatturahman. 2016. Model-model pembelajaran Inovatif. Yogyakarta : Arruz Media

[9] Depdiknas, (2008). Panduan Pengembangan Bahan Ajar. Direktorat Jendral Manejemen Pendidikan Atas. Jakarta

[10] Riyant0, Y. (2014). Paradigma Baru Pembelajaran. Jakarta : Prenada Media Group

[11] Irma Suwarma, Astuti Puji dan Nur Endah. (2015). Ballon Powered Car "sebagai media pembelajaran IPA berbasis STEM (Science Technology Engineering Mathematic). 8 dan 9 Juni 2015. Prosinding Simposium Naisonal Inovasi dan Pembelajaran Sains. Bandung

[12] Ismayani, A. (2016). Pengaruh Penerapan STEM Project Based Learning Terhadap Kreatifitas Matematis Siswa SMK. Indonesia Digital Journal of Mathematics and Education. Vol 3 (264-272)

[13] Departement of Education and Skill Ireland. (2017). STEM Education Policy Steatment 2017-2026. Ireland

[14] Khairiyah, N. (2019). Pendekatan STEM Referensi Standar untuk melakukan pembelajaran dikelas agar lebih efektif dan efesien. Medan: Guepedia

[15] Gustiani, I., Widodo, A. , Suwarna, I.R. (2017). Development and Validation of STEM based Instructional Material. MSCEIS 2016.

[16] Kementrian Pendidikan Malaysia. (2016). Panduan Pelaksanan Sains, Teknologi, Kejuruteraan, dan Matematik (STEM) dalam Pengajaran dan Pembela-jaran. PutraJaya

[17] Utami, TN, Jatmiko, A dan Suherman. (2018). Pengembangan Modul Ma-tematika dengan Pendekatan Science, Technology, Engineering, and Math-ematics (STEM) pada Materi Segiempat. Jurnal Matematika 1(2):165-172. Universitas Islam Negeri Raden Intan. Lampung
[18] Tung. (2016). Desain Instruksional Perbandingan Model dan Implementasinya. Yogyakarta : PT Andi

[19] Riduwan. (2012). Skala Pengukuran VariabelVariabel Penelitian. Bandung : Alfabeta

[20] Widyoko, EP. (2017). Teknik Penyusunan Instrumen Penelitian. Yogyakarta : Pustaka Belajar

[21] Juniarti, Zubaidah, S. dan Koes, S. (2016). STEM: Apa, Mengapa dan Bagaimana? Prosinding Seminar Nasional Pendidikan Sarjana Pascasar-jana UM. Vol 1

[22] Syukri, M., Halim, L., Meerah, T. S. M., \& FKIP, U. (2013, March). Pendidikan STEM dalam Entrepreneurial Science Thinking 'ESciT': Satu Perkongsian Pengalaman dari UKM untuk ACEH. In Aceh Development International Conference (pp. 26-28).

[23] Khoiriyah, N. (2018). Implementasi pendekatan pembelajaran STEM untuk meningkatkan kemampuan berpikir kritis siswa SMA pada materi gelombang bunyi. 